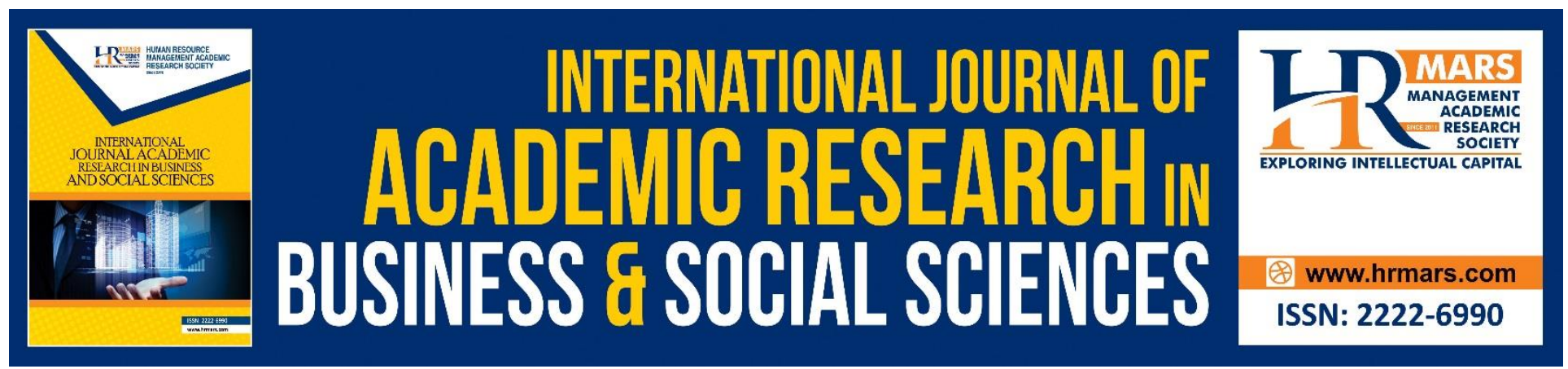

\title{
Analysis and Evaluation Dimension: Strengthening The Integrity of Political Participation Practice in Social Media from Media Literacy Perspective
}

Mohd Sufiean Hassan, Siti Nurshahidah Sah Allam, Zaliffah Abd. Wahab, Rosilawati Sultan Mohideen, Dzaa Imma Abdul Latiff

To Link this Article: http://dx.doi.org/10.6007/IJARBSS/v10-i11/7848

DOI:10.6007/IJARBSS/v10-i11/7848

Received: 06 September 2020, Revised: 25 September 2020, Accepted: 12 October 2020

Published Online: 09 November 2020

In-Text Citation: (Hassan, et al., 2020)

To Cite this Article: Hassan, M. S., Allam, S. N. S., Abd. Wahab, Z., Mohideen, R. S., Abdul Latiff, D. I. (2020). Analysis and Evaluation Dimension: Strengthening The Integrity of Political Participation Practice in Social Media from Media Literacy Perspective . International Journal of Academic Research in Business and Social Sciences. 10(11), 123-140.

\section{Copyright: (c) 2020 The Author(s)}

Published by Human Resource Management Academic Research Society (www.hrmars.com)

This article is published under the Creative Commons Attribution (CC BY 4.0) license. Anyone may reproduce, distribute, translate and create derivative works of this article (for both commercial and non-commercial purposes), subject to full attribution to the original publication and authors. The full terms of this license may be seen

at: http://creativecommons.org/licences/by/4.0/legalcode

Vol. 10, No. 11, 2020, Pg. 123 - 140 


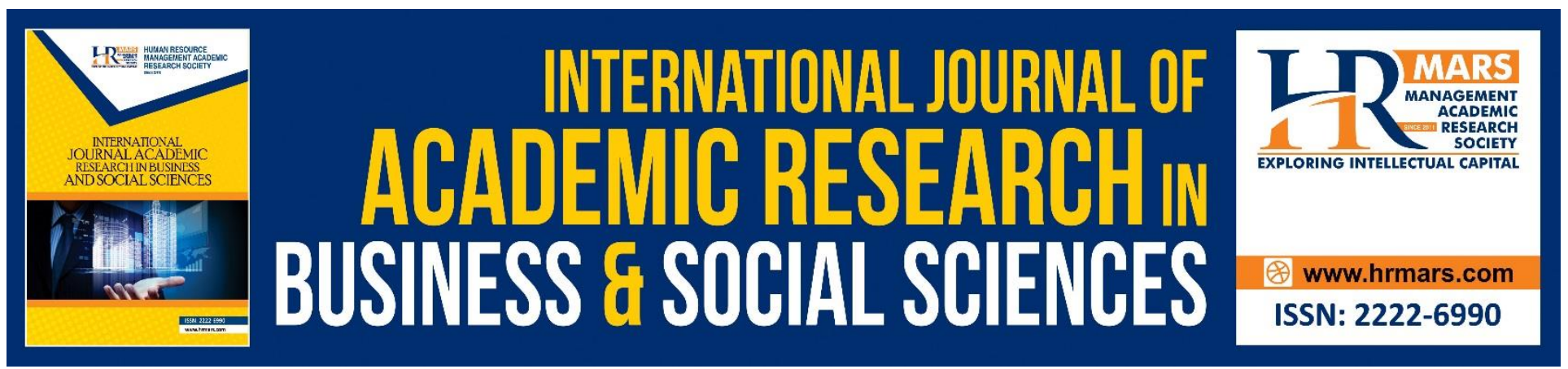

\title{
Analysis and Evaluation Dimension: Strengthening The Integrity of Political Participation Practice in Social Media from Media Literacy Perspective
}

\author{
Mohd Sufiean Hassan \\ Kolej Universiti Islam Melaka, Malaysia
}

Siti Nurshahidah Sah Allam

Universiti Teknologi MARA, Melaka Branch, Malaysia

Zaliffah Abd. Wahab

Universiti Teknologi MARA, Shah Alam, Malaysia

Rosilawati Sultan Mohideen

Universiti Teknologi MARA, Melaka Branch, Malaysia

\section{Dzaa Imma Abdul Latiff}

Universiti Teknologi MARA, Negeri Sembilan Branch, Malaysia

\begin{abstract}
The planned public street demonstration, spark provocation, create drastic social mobility, disseminate defamatory information, and seduction to bring down the individual's reputation, spread fake news, pressure the government through street rallies, and eventually led to drastic changes to the country's socio-politics. Eager to enhance young people's political engagement through social media embedded with integrity values and disseminate moral conduct towards social media communities, this study aims to identify the effect of analysis and evaluation dimension from a media literacy perspective. A total of 388 questionnaires was collected from four universities in Melaka, Malaysia. Data were analysed using SPSS Amos -Structural Equation Modelling (SEM). This study found that analysis and evaluation have a significant and positive influence on the integrity of political participation among young people in social media. This study highlights that young people's engagement in political activities with integrity values can enhance social media's moral conduct among web communities.
\end{abstract}

Keywords: Media Literacy, Analysis And Evaluation, Integrity Value, Political Participation, Young People, Social Media, Political Integrity 
INTERNATIONAL JOURNAL OF ACADEMIC RESEARCH IN BUSINESS AND SOCIAL SCIENCES Vol. 10, No. 11, 2020, E-ISSN: 2222-6990 @ 2020 HRMARS

\section{Introduction}

Malaysia, as a democratic country, has gone through a phase in which young people are reported to have a low interest in political participation (Mohamed et al., 2011), and a detailed study on the study of these low-interest factors opens up the academic research space (Joko et al., 2016) and public discussion (Sudin, 2017). However, the wave of political participation of young people has dramatically changed the country's political sphere (Husnu \& Mamat, 2016) and not only stopped there. This wave created a tsunami disaster (Norhayati, 2008) when the superior government ruled Malaysia, the BN government lost a majority, leading to a government change in the 13th General Election (Pandian, 2014). This scenario is reported to impact social media use by young people in political participation (Kasmani et al., 2014). The greater social media use reported greater political knowledge that led to greater political participation among young people (Hassan et al., 2013).

Social media innovations have been reported to increase awareness, inclination, and interest in politics, especially among young people (Tang \& Lee, 2013). Compared to conventional media such as television, radio, and newspapers but the new media offers interactive applications, fast information search agents, and effective communication (Dauda et al., 2016). The emergence of social media networking sites has created a new wave of paradigms in society, especially for young people in political participation.

According to Coleman, Morrison \& Svennevig (2008) social media is a platform that facilitates cooperation in forming national solidarity and forming groups with the same political ideologies. Users easily obtain information from a wide range of sources and disseminate without geographical restrictions on social platforms (Conroy et al., 2012). Popular social media such as Facebook, Twitter, Flickr, LinkedIn, and Instagram offer interactive platforms (Salman \& Hasim, 2011) and are effective in communicating, shaping humanitarian relationships at both national and global levels, sharing information and knowledge. Besides, social media use significantly spark form a broad social movement to empower the political participation of young people (Al-Kandari \& Hasanen, 2012). However, these developments have created increasing concerns about the value of integrity of young people's political participation (Hassan et al., 2020).

The impact of a high frequency of social media uses in reinforcing the political tendency of young people to be discussed (Alhabash \& Ma, 2017; Chan \& Guo, 2013; Yoo \& Gil de Zuniga, 2014) and reported that the use of social media leads to lower levels of integrity among young people (Hassan et al., 2013). This high level of social media use leads to non-intrusive activities such as provocation (Kumar, 2016), disseminating defamatory information, and seduction to bring down the individual's reputation (Husnu \& Mamat, 2016), spread fake news (Harper, 2017), aims to pressure the government through street rallies and eventually led to drastic changes to the country's sociopolitics (Mohd Sani, 2014).

Therefore, this study believes that the value of integrity through media literacy (Sah Allam et al., 2020) can curb misconduct and foster morale among young people (Pathak-shelat, 2014) in social media in terms of analysis and evaluation. Although research on the political participation of young people in social media extensively (Bahtiar et al., 2018; Demetriou, 2013; Fenton, 2011; Omelicheva \& Ahmed, 2017; Stockemer, 2012; Yang \& DeHart, 2016) but media literacy perspective, particularly in terms of analysis and evaluation are less tested while the ability of young people to analyze the political content in social media is based on the ability to access sources of political, analyze the content of political resources and access the political content in social media is important in shaping the political knowledge. 
INTERNATIONAL JOURNAL OF ACADEMIC RESEARCH IN BUSINESS AND SOCIAL SCIENCES Vol. 10, No. 11, 2020, E-ISSN: 2222-6990 @ 2020 HRMARS

Research on the literacy media from the analysis and evaluation aspects have received little attention from social or socio-political sciences than studies on the level of political knowledge (Zhang \& Lin, 2014; level of political participation, and type of political participation of young people. Studies on the political information efficacy (Kaid et al., 2007; Tedesco, 2011) as a factor of political participation of young people is assessed from the level of political knowledge (Ashley \& Maksl, 2017; Dimitrova et al., 2014; Milner, 2007) than skills to analyze and assess political sources used by young people in social media. Most of these studies did not test the level of skill in analyzing and evaluate political sources because the level of political knowledge is only a factor of political interest (Holt et al., 2013) and does not test the level of integrity values (Bakker, 2007).

Besides, the analysis and evaluation studies more often a concern in education (Cheung \& Xu, 2016; Roy, 2016), which led to the effectiveness of the analysis and evaluation skills in teaching and learning for the students and the testing is a purposive sampling (Arke \& Primack, 2009; Literat, 2014; Young \& Marcos, 2016) rather than the random sampling that is often used to study the political participation of young people. Purposive sampling easier in data collection and reduce the probability of low levels of validity and reliability study data (Hobbs, 2003).

For the study of political participation of young people on social media, most researchers are directed towards the type of social media (Effing et al., 2011), frequency of social media usage (Valenzuela, 2013), and the impact of the use of social media which contributes to a higher tendency for more aggressive political participation (Omelicheva \& Ahmed, 2017; Valenzuela, 2013; Zhang \& Lin, 2014) rather than the integrity of political participation (Hassan et al., 2013).

Therefore, this study aims to examine the effect of analysis and evaluation on the integrity of political participation among young people. This research's idiosyncratic contribution arises from this factor's effects on the integrity of political participation among young people, which the study enhanced with additional information to narrow the research gap. The research makes a novel empirical contribution and provides useful insights by testing the proposed theoretical framework on the integrity of political participation among young people in Malaysia.

This study opens a platform for discussion on media literacy, particularly in terms of analysis and evaluation in promoting the integrity of young people's political participation in social media. This discussion's direction was opened up knowledge about media literacy perspective and political participation of young people, especially in social media. Next, this paper focuses on the media literacy perspective in terms of analysis and evaluation on shaping young people's integrity in social media.

\section{Young People of Political Participation in Malaysia}

The history of young people's political participation began around the early 1900s led by former students from West Asia who came back to fight for freedom, progress, and independence spread through the Al-Imam Newspaper, which was an effective platform for disseminating information at that time (Wan Hashim, 2017). Here comes the beginning of Kesatuan Melayu Muda (KMM) was established in May 1930 to fight for National Independence and other anti-British struggles.

Political developments continued to grow up to form political parties. Starting with Malayan Union (April 1, 1946), UMNO (May 11, 1946), MCA (February 27, 1949), and MIC (August 1946). Then in 1952, UMNO, the MCA, and the MIC merged and formed an Alliance party. Until the establishment of these political parties, young people were still using traditional media mediums (newspapers, 
INTERNATIONAL JOURNAL OF ACADEMIC RESEARCH IN BUSINESS AND SOCIAL SCIENCES Vol. 10, No. 11, 2020, E-ISSN: 2222-6990 @ 2020 HRMARS

journals, and magazines) to disseminate information and broaden the thinking of young people at that time.

From Malaysian history, young people's political participation is active and aggressive in their struggle until destabilizing the country. Those who initiate these movements are knowledgeable and well-educated groups from universities within and outside the country (Al-Maniri, 2014). Their contribution is mounted with the open innovation social media platform to effectively express their ideas and opinions (Maamari \& Zein, 2013).

Students pelted reported outspoken opinions on government and governance efficiency and changed the country's political situation. This is proven when the young people's impact during the 13th General Election triggered the Political Tsunami phenomenon (Norhayati, 2008). The political participation of young people leading a wave of change prompted the government to start hearing these young people's voices.

Apart from the contribution of young people to the country's administration, this group also reported contributing to the integrity of political participation. According to Mat Din et al. (2013), young people seek their political leaders' personalities with a good value of integrity such as having good relationships with others, prevent themselves from morals wrong, have respect and abide by the social structures. This directly contributes to the political participation of young people $(\mathrm{Hj}$ Mak Din \& Stapa, 2016).

This study was supported by Picone, De Wolf, \& Robijt, (2016), who reported that young people are effectively described as transformational agents that reinforce the value of integrity to other young people through socializing agents.

This refers to the role of young people in controlling unethical behavior on social media and an agent of social campaigns among netizens (Marwick, \& Boyd 2011). Thus, young people's contribution is towards the nation's progress and development and shaping political morals ideology through the integrity of political participation, especially on social media to young people.

\section{Media Literacy Perspective: Analysis and Evaluate Effect Integrity Practice of Political Participation among Young People in Social Media}

The effects of exposure to media content on the individual and society have led to the media literacy model's development. This model's main idea is to guide media users, particularly young people who use the media based on the value of integrity. According to Hobbs (2010), skills in analysis and evaluation refer to users with critical thinking; practices compose a message, creative in creating digital content, and engaging in ethics. When a person has media literacy competencies, they recognize others' rights, cultural and political agendas and exercise their right to speak based on the value of integrity (Aufderheide 1993; Hobbs 2010).

Aspects of analysis and evaluation of media literacy skills are considered important because, through the media and users, young people can act as a producer on the content of the media, especially in social media. Therefore, most researchers in psychology, sociology, media, and sociopolitical liberal believe that the ultimate goal of media literacy is to measure media use and the ability to analyze information in the media (Eristi \& Erdem, 2017). After accessing media content, a set of competencies, such as analysis and evaluation, is required. This competency includes analyzing information sources and evaluating sources from multiple sources (Lewis, \& Jhally 1998).

This analysis and evaluation also refer to the ability to understand information, think critically on information sources, and compare different sources. Besides, this aspect of analysis and 
INTERNATIONAL JOURNAL OF ACADEMIC RESEARCH IN BUSINESS AND SOCIAL SCIENCES Vol. 10, No. 11, 2020, E-ISSN: 2222-6990 @ 2020 HRMARS

evaluation measures young people's ability to seek political information and ensure the integrity of information characterized by authentic information, accurate and ethical, and moral values (Hobbs, 2010).

Analysis and evaluation aspects are becoming more significant to young people because of the faster adoption of technologies than adults. Interest in exploring new technology applications directly enhances access to information and thus led to the analysis and evaluation of resources (Lee, 2005). Besides age motivation, young people's educational level is an indicator of the ability to analyze and evaluate information sources to obtain accurate and authentic information.

Arsenijević supported this idea, \& Andevski (2016), who conducted a media literacy study on the academic community in Serbia, found that education through the field of study plays a major role in the area of information analysis and evaluation, where the technical-technology field has a higher level of information analysis and evaluation than social science. However, social sciences also contribute to analysis and evaluation, in which the cognitive and psychomotor skills implemented in the syllabus directly generate critical thinking (Persson, 2013).

Besides, the adaptation of technology young people are also significant to the analysis and evaluation as an element of social media applications offer interaction interactive (Hafez, 2016), access to information easier than traditional media (TV, Radio, and Newspaper) (Ali et al., 2011), analysis and evaluation process faster because the data and information more readily available through the Search Engines (Search Engine) and this directly increases the tendency of youth politics.

This justification is also supported by Maamari \& Zein (2013) in their study of young people in Lebanon and found that when high levels of technology adaptation, especially social media, increase the political tendency of young people. social media offer new communications platform that is more strategic as providing interaction receive an immediate response (Kumar, \& Thapa 2014), dissemination of information more extensive and ease of use (Anom et al., 2014; Plotkowiak, 2014), latest information flow, easy and cheap to reach. (Ali et al., 2011).

\section{The Level of Adaptation of Technology using Social Media and the Ability to Analyze and Evaluate News Sources}

The analysis and evaluation aspect is considered major media literacy skills. This is because media literacy's main goal is to measure the ability to analyze information in the media and media use (Eristi \& Erdem, 2017). After accessing media content, a set of competency that is analysis and evaluation required. This competency includes analyzing the information and evaluating sources from numerous references (Lewis, \& Jhally 1998).

Young people are a significant group associated with social media because of the faster adoption of technology than adults. The interest in exploring technology applications directly enhances access to information, leading to aspects of analysis and resource evaluation (Lee, 2005). In addition to age motivation, young people's education level is an indicator of their ability to analyze and evaluate information sources to obtain accurate and valid information.

Besides, the adaptation of technology young people is also significant to the analysis and evaluation as an element of social media applications offer interactive interaction (Hafez, 2016), access to information much easier than traditional media like television, radio, and newspapers (Ali et al., 2011) the process of analysis and evaluation is faster as data and information are made more accessible through the search engine function and directly enhances the political inclination of young people. 
INTERNATIONAL JOURNAL OF ACADEMIC RESEARCH IN BUSINESS AND SOCIAL SCIENCES Vol. 10, No. 11, 2020, E-ISSN: 2222-6990 @ 2020 HRMARS

Moreover, Maamari dan Zein (2013) found that when high levels of technology adaptation, especially social media, will increase young people's political inclination. This justification supported that new technology encourages the political inclination of young people. Moreover, social media offer new communications platform that is more strategic providing with the instant response of interaction (Kumar, \& Thapa 2014), dissemination of information is more comprehensive and faster (Anom, Kee \& Zawawi 2014; Plotkowiak 2014), up-to-date information, easy to use, and cheap (Ali et al., 2011).

Therefore, the contribution of the political analysis and evaluation of information depending on the degree of adaptation of social media technology led to the ability to explore social media applications to analyze and assess the diversity of political information sources. This adaptation enables the process of analyzing and evaluating sources of political information more efficiently than accessibility.

\section{Analyse and Evaluate Political Information Sources in Social Media}

Analysis and evaluation emphasize that the ability to compare political information on social media affects young people's level of media literacy (Ojebuyi \& Salawu, 2015). In the age of information overflow and technological boom, young people with high political interest levels are more likely to have high political knowledge (Wolfsfeld et al., 2015).

These are known as political information repertoires, the variety of sources used by young people to understand political information (Taneja et al., 2012). This high level of political knowledge is achieved through analysis and evaluation of news sources from various sources, especially on social media, where exposure to provocative political information analysis directly reduces the level of political participation of young people on social media (Min, 2004; Pinkleton \& Austin, 2002).

Studies on social media and political participation have reported a significant relationship between social media and political information search by young people (Yang \& DeHart, 2016; Conroy, Feezell \& Guerrero, 2012). This is because political information on social media is derived from interactions with friends and other netizens by uploading and downloading political information from other social media user accounts. This interaction process involves the sharing of ideas, information, and opinions that are both accurate and high quality, encouraging young people to use social media (Edgerly et al., 2016).

Correa, Hinsley \& Zúñiga (2010) emphasize that the higher the quantity and quality of information, the higher the number of individuals engaged in online politics. Similarly, Abdu, Mohamad \& Muda (2017) argue that young people are more likely to participate in politics due to the impetus for the quality of information and the need for their political information obtained on social media compared to other media. This allows for improved information sharing because of the desire to know and obtain accurate political information.

This idea was supported by Abdu et al. (2017) in their study social media use, political information quality on social media, and political tendencies in influencing the political participation of young people. They discovered the key aspects of political participation are social media, the quality of political information, and young people's political tendencies. This proves that comparing sources of information on social media directly affects the level of political participation.

The value of integrity is achieved through the comparative quality of political information (Wolfsfeld et al., 2015), where political information positively impacts civic activity in society (Trenz, 2015), strengthens the practice of national democracy (Chang 2017), and belief in the political system 
INTERNATIONAL JOURNAL OF ACADEMIC RESEARCH IN BUSINESS AND SOCIAL SCIENCES Vol. 10, No. 11, 2020, E-ISSN: 2222-6990 @ 2020 HRMARS

(Valenzuela et al., 2009), where this value of trust refers to the integrity and efficiency of the leadership system, the efficiency and moral value of coping with political pressures, and prioritizing responsive actions to the people (Carlin, 2014).

However, previous studies also reported that political information, especially news on social media, had higher levels of provocative political information than conventional media (TV, Radio, and Newspapers) because political information on social media was not edited as a public reading, so it contained provocative information, slander, and issues of political sensation that are not reported in conventional media (Hassan et al., 2013). Therefore, it is important for social media users, especially young people, to understand aspects of analysis and evaluation when comparing political information sources on social media before such information is used or disseminated.

\section{Use Valid Sources for Political Information in Social Media enhance Analysis and Evaluation Skills} The study of media literacy from the perspectives of analysis and evaluation through the use of information sources in social media found that young people who are using social media as a source of political information tend to click the comment, like, share, retweet, and share information with other netizens (Marwick, \& Boyd 2014).

Using political information in social media and share with netizens is based on several motives. According to Kümpel, Karnowski, \& Keyling (2015), sharing political information is divided into three. The first one is the desire to express opinions, second, the desire to share political information with other users, and third, the desire to create online social interactions. Among these motives, the desire to create online social interaction was reported to be dominant because the main motive of using social media was to connect and interact with netizens, as well as the desire to share political information (Kumar, \& Thapa 2014).

Social media offers unlimited communication platforms, anywhere in the world, to anyone sharing political interests across the global political system's borders across geographical diversity (Iskander, 2011). The new media is reported to have changed the way the global community communicates; Online interaction speeds up feedback (Al-Kandari \& Hasanen, 2012), an interaction that allows social media users to give an idea, opinion, criticize, and discussion on social and political issues openly and transparent (Oliveira \& Garcia, 2019; Valenzuela, 2013).

The spherical change of communication methods has been reported to trigger the number of followers and the highest reader through viral. This phenomenon triggers various issues of young people's integrity as reported by Berger, \& Milkman (2012) in a study of how advertising content, video, and online news became viral. This study's findings show that there is a significant relationship between the viral elements and the content of provocative information such as provocation, slander, and sensational than an informative article or something formal reporting the news.

This content is closely linked to the injection of emotions stimulated by viral content such as angry, resentment, anxious, and fearful emotions (Nisbet \& Myers, 2011; Sheedy, 2011). Sensational news is the news people need to know compared to the news they want to know. Adopting a flexible news approach makes this information more emotionally accessible than technical (Picone, Wolf \& Robijt 2016).

The viral phenomenon directly brings a negative impression is expected to overcome the ability and skills of young people and use authentic political information and understand the effects of unprofessional use of political information. The sharing and use of provocative political information directly propel the rise of aggressive actions (Al-Kandari \& Hasanen, 2012), protests (Valenzuela, 
INTERNATIONAL JOURNAL OF ACADEMIC RESEARCH IN BUSINESS AND SOCIAL SCIENCES Vol. 10, No. 11, 2020, E-ISSN: 2222-6990 @ 2020 HRMARS

2012), demonstrations against political systems, and leadership (Zhang, \& Lin 2014) street demonstration (Salman \& Saad, 2015). Therefore, the validity of political information needs to be analyzed and evaluated before it is used and shared with other netizens. This aspect demonstrates the value of integrity in the political participation of young people. Based on these arguments, this study builds on the following hypothesis:

$\mathrm{H1}$ : Analysis and evaluation aspect significantly influences the integrity of political participation among young people

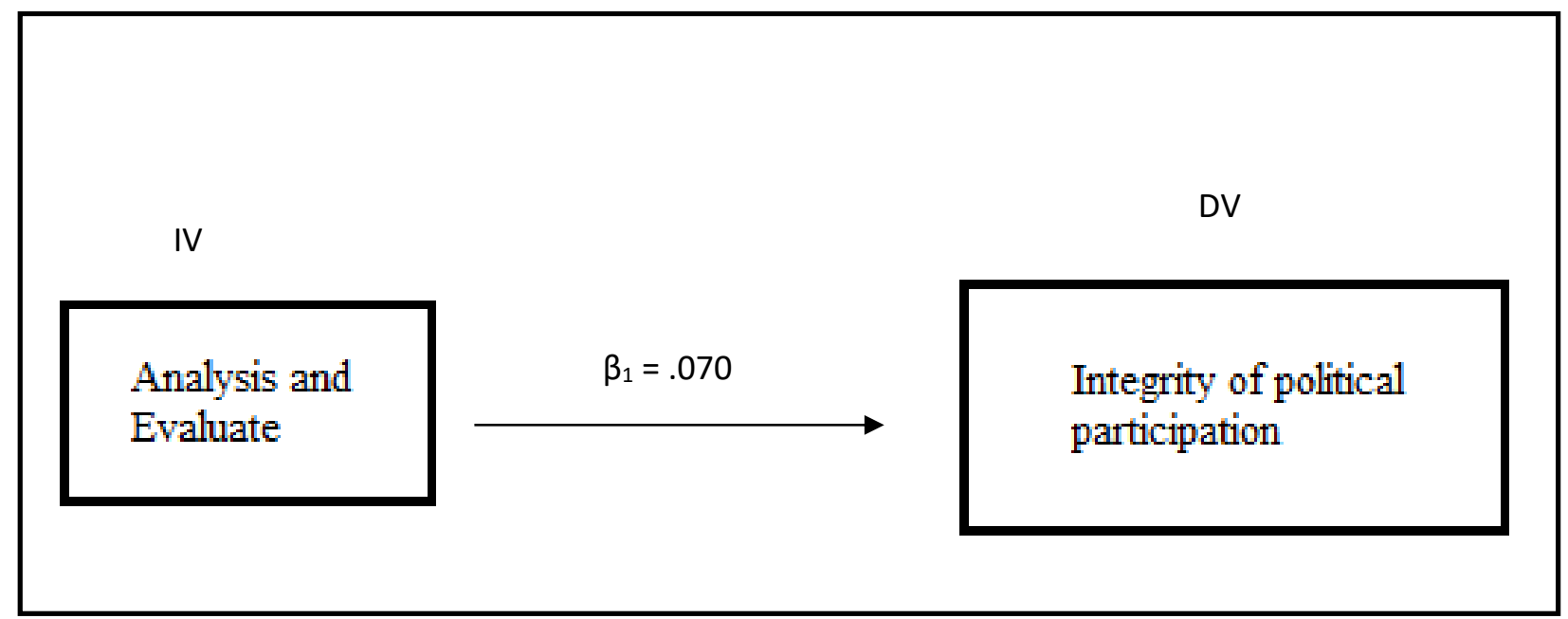

Figure 1 : Research model

\section{Research Methodology}

The respondents of this study were 388 Higher Education Institutions (HEI) students comprising four universities in Melaka, Malaysia. Student selection was based on random sampling. This research uses the survey as a means of collecting data. Based on the number of respondents $(n=388)$ with comprehensive data in this study, the sample size is large enough for the use of Structural Equation Modelling (SEM) (Hair, Black, Babin \& Anderson, 2010). Before moving to the final data collection, a pilot study conducted to test the instrument's reliability was conducted to ensure the questionnaire's consistency. Cronbach Alpha's reliability coefficient for all four variables, above 0.70 , shows a good internal consistency (Hair et al., 2010).

The questionnaire consists of two parts. Part A consists of general information on demographic variables such as gender, age, status, race, education, and social media usage. Part B contains a media literacy scale adapted from Koc \& Barut (2016). The scale to measure media literacy is a wellestablished scale that has proven its reliability because it is widely used in past studies. The reliability Cronbach Alpha for all five media literacy is between $0.89-0.92$. The steady use of the scale helps in terms of the scale's reliability in gaining information through the public (Babbie, 2013). This scale contains 33 items and is measured using a seven-level interval scale of $1=$ strongly disagree to $7=$ strongly agree. This measurement scale measures access, analysis, and evaluate, create, reflect, and act.

The data were analyzed using the descriptive analysis to describe the respondents' profile, and Confirmatory Factor Analysis (CFA) was performed using AMOS 21.0. The CFA seeks to determine the 
INTERNATIONAL JOURNAL OF ACADEMIC RESEARCH IN BUSINESS AND SOCIAL SCIENCES Vol. 10, No. 11, 2020, E-ISSN: 2222-6990 @ 2020 HRMARS

number of items included in the construct inline with the theory (Byrne, 2016). The goodness-of-fit of the CFA model was determined based on a combination of at least one Absolute Fit Indices and one Incremental Fit Indices (Bentler \& Chou, 1987; Hair et al., 2010) and Parsimony Fit Indices (PFI) (Hair et al., 2010). Measurement goodness-of-fit is to determine whether the model tested should be accepted or rejected. However, according to Burroughs, Brocato, Hopper, \& Sanders, (2009) and Hair et al., (2010), there is no specific rule that determines goodness-of-fit index. Hair, Black, Babin, \& Anderson, (2014) suggested that at least three or more goodness indexes are sufficient to prove that a model achieves goodness-of-fit without reporting all of the existing goodness-of-fit indexes.

\section{Result}

There were 388 students who participated in the survey with 165 of them males and 223 females. 9.5 percent of the students, or 37 of them, are between the age of 18-20, 54.9 percent of the students, or 213 of them, are between 21-23, 22.7 percent of the students, or 88 of them, are between 24-26, 9.5 percent of the students, or 37 of them, are between 27-29, and the remaining 3.4 percent of the students, 13 of them, are aged between 30-40 years. The survey revealed that more than $85 \%$ of the respondents are married. The majority of the respondents have been educated to college or higher education level: $2.6 \%$ are STPM, 3.6\% are Matriculation, $2.6 \%$ are pre-diploma, and $59.8 \%$ diploma holders while $32 \%$ have Bachelor degrees. In addition, $49.2 \%$ of the respondents used social media more than ten times a day and $29.6 \%$ have used to update social media accounts 1-30 minutes once.

\section{Confirmatory Factor Analysis of (CFA) Analysis and Evaluation}

Table 1 Confirmatory Factor Analysis (CFA)

\begin{tabular}{lllllllll}
\hline Description & $\chi^{2}$ & CMINDF & RMSEA & GFI & IFI & TLI & CFI & PGFI \\
\hline Model CFA & 64.887 & 2.093 & 0.053 & .967 & .987 & .980 & .986 & .545 \\
\hline
\end{tabular}

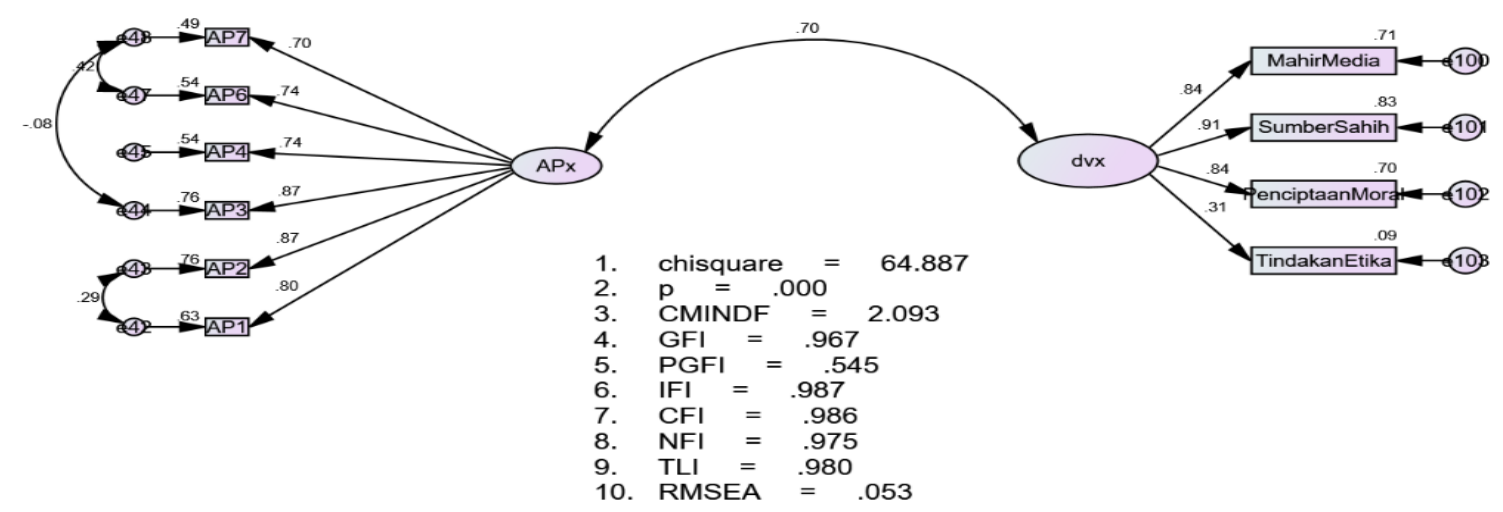

Figure $2 \quad$ CFA Model

Measurement Model in table 1 showed a good model fit with eight indicators namely $(\chi 2$, CMINDF, RMSEA, GFI, IFI, TLI, CFI, and PGFI) as shown in table 1. However, Marsh \& Hau (1996) suggested that Chi-square $(\chi 2)$ value can be divided with a degree of freedom $(\mathrm{df}=100)$ to assess model fit compared to $\chi 2$ (CMINDF). If counting statistics CMINDF less than value 5 , the data is fit for 
INTERNATIONAL JOURNAL OF ACADEMIC RESEARCH IN BUSINESS AND SOCIAL SCIENCES Vol. 10, No. 11, 2020, E-ISSN: 2222-6990 @ 2020 HRMARS

confirmatory factor analysis model is good (Marsh \& Hau, 1996). CMINDF for this measurement model is less than value 5 (CMINDF = 2.093). This shows that the CFA model is quite good. Furthermore, the RMSEA value is 0.057 which is lower than .08 as suggested by Kline (2010). The index coefficients in Table 1 were all greater than 0.90 indicating good model fit (Byrne, 2016), and PGFI values greater than 0.5 (0.545) which also showed good model fit with the data (Hair, et al., 2010). Five (5) items were combined due to the high modification indices value (M.I). Figure 1 shows the CFA Model for this study.

Table 2: Structural Equation Modelling Analysis

\begin{tabular}{lllllllll}
\hline Description & $\chi^{2}$ & CMINDF & RMSEA & GFI & IFI & TLI & CFI & PGFI \\
\hline $\begin{array}{l}\text { Full } \\
\text { Model }\end{array}$ & 64.887 & 2.093 & 0.053 & .967 & .987 & .980 & .986 & .545 \\
\hline
\end{tabular}

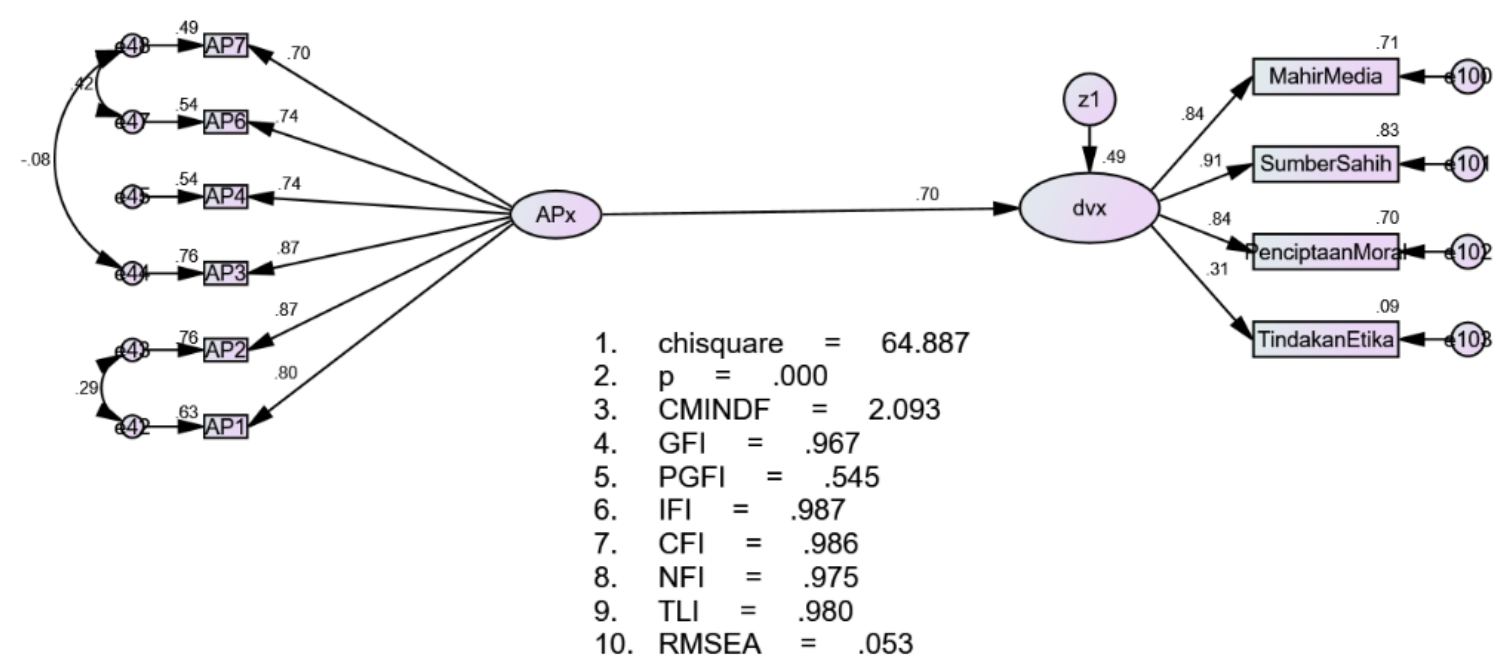

Figure 3: SEM Model

Table 3: Standardized Regression Model

\begin{tabular}{|c|c|c|c|c|c|c|c|}
\hline \multicolumn{8}{|c|}{ Standardized Regression Weight) / Path coefficient } \\
\hline & & & & Standard $(\beta)$ & S.E. & C.R. & $P$ \\
\hline $\begin{array}{l}\text { Integrity of } \\
\text { Participation }\end{array}$ & Political <--- & $\begin{array}{l}\text { Analysis } \\
\text { Evaluate }\end{array}$ & and & .70 & .443 & 12.291 & $* * *$ \\
\hline
\end{tabular}

\section{Discussion}

The confirmatory factor analysis (CFA) model with the construct's validity also gives the impression that the analysis and evaluation constructs in the digital competency model and media literacy have been validated to represent the construct. The findings show that the analysis and evaluation aspects from media literacy reported significantly positive influence for participation political integrity with a $70 \%$ variance contribution. This indicates that this efficiency is important to note, as it contributes significantly to young people's political participation on social media.

How analysis and evaluation skills reinforce the integrity of political participation among young people? and how this skill can enhance moral conduct among social media communities? 
Analysis and evaluation dimensions reported significantly influence political participation integrity among young people by searching for political information in social media. The notion is the higher searching intention, the greater political knowledge they can get, and the merrier political information sources they are exposed to.

Young people develop analysis and evaluation skills by scrutinizing various sources' information to develop their understanding of political issues. The output from this critical analysis skills expected young people to produce a new political angle useful for social media communities' political knowledge. Eligible sources, truth, and trustworthy information are the key points for positive analysis that young people produce to share and consume by the social media community.

However, lack of analysis and evaluation skills expected our young people possess low integrity values in using social media such as creating provocation in political discourse platform, liking, commenting (Carey \& Meyer, 2016), sharing fake political information, and catalyst racism issue (Chetty \& Alathur, 2019). Besides, low media literacy skills reported young people to disseminate slander purposely to demoralize political party images or become trending, viral, or popular young people in social media (Beldad, 2015). High media literacy skills, especially in analysis and evaluation dimensions, were reported to reduce and control young people's misbehavior in social media.

Reflecting as a change agent, young people, especially in higher education, can promote integrity values and moral conduct in social media by providing fruitful political discussion platforms, uploading new political information with new perimeters, and leaving positive comments in a political forum. Basically, these are the types of engagement that strengthening the integrity of political participation among young people. From the ethical engagement, our young people disseminate integrity values and promoting moral conduct in an online platform for social media communities.

\section{Corresponding Author}

Siti Nurshahidah Binti Sah Allam, Universiti Teknologi MARA, Melaka, shahidah321@uitm.edu.my.

\section{Conclusion}

The current study found that analysis and evaluation skills from a media literacy perspective significantly influence political participation integrity among young people in social media. Besides, analysis and evaluation skills among young people are expected to enhance their political interest through social media use and encourage moral conduct. Providing new angles in political discourse, giving positive comments in a political debate, ignoring any provocative messages, avoiding sharing harsh political content, and escaping negative political information significantly affect young people political engagement with high political integrity values in social media. From political participation integrity, young people are expected to disseminate integrity values and promote moral conduct in an online platform among social media communities. The previous study reported that young people have high media literacy skills. Therefore, this study reported complements and enhances the findings of media literacy and political integrity by having high analysis and evaluation skills; young people tend to express their idea and engage in online political discourse ethically. This study highly contributed to the Malaysian Communications and Multimedia Commission who promoted Media Literacy education to combat integrity issues in socia media among Malaysian young people. The current study provide empirical model for Media Literacy implementation in national level. In addition, this study highly contributed to the body of knowledge on political communication from the 
INTERNATIONAL JOURNAL OF ACADEMIC RESEARCH IN BUSINESS AND SOCIAL SCIENCES

Vol. 10, No. 11, 2020, E-ISSN: 2222-6990 @ 2020 HRMARS

perspective of Media Literacy that isolated topic to be discussed among communication and media scholars.

\section{References}

Abdu, S. D., Bahtiar, M., \& Suhaini, M. (2017). Youth online political participation: the role of Facebook use, interactivity, quality information and political interest. SHS Web of Conferences, 33(1), 1-10.

Alhabash, S., \& Ma, M. (2017). A Tale of Four Platforms: Motivations and Uses of Facebook, Twitter, Instagram, and Snapchat Among College Students? Social Media + Society, 3(1), 1-13.

Al-Kandari, A., \& Hasanen, M. (2012). The impact of the Internet on political attitudes in Kuwait and Egypt. Telematics and Informatics, 29(3), 245-253.

Al-Maniri M. S. (1995). Politik kampus di sebalik tadbir. Pustaka Generasi Baru.

Anom, E., Kee, C. P., \& Zawawi, J. W. M. (2014). Political discourse in Indonesia and Malaysia for national human security: a case study of Lahad Datu. Jurnal Komunikasi, 30(2), 183-200.

Arke, E., \& Primack, B. A. (2009). Quantifying media literacy: development, reliability, and validity of a new measure. Educational Media International, 46(1), 53-65.

Arsenijević, J., \& Andevski, M. (2016). New media literacy within the context of socio-demographic characteristics. Procedia Technology, 22(1), 1142-1151.

Ashley, S., \& Maksl, A. (2017). News media literacy and political engagement: what's the connection? Journal of Media Literacy Education, 9(1), 79-98.

Aufderheide, P. (1992). Media Literacy: A Report of the National Leadership Conference on Media Literacy. In Media literacy in the Information age current perspectives 6 (2). http://www.eric.ed.gov/ERICWebPortal/search/detailmini.jsp?_nfpb=true\&_\&ERICExtSearch_ SearchValue_0=ED365294\&ERICExtSearch_SearchType_0=no\&accno=ED365294

Babbie, E. (2013). The Practice of Social Research (13th ed.). Wadsworth, Cengage Learning.

Bahtiar, M., Shamsu, A. D., \& Haslina, H. (2018). Youth offline political participation: Trends and role of social media. Jurnal Komunikasi, 34(3), 192-207.

Bakker, E. (2007). Integrity and cynicism: Possibilities and constraints of moral communication. Journal of Agricultural and Environmental Ethics, 20(1), 119-136.

Bakker, T. P., \& Vreese, C. H. (2011). Good news for the future? Young people, internet use, and political participation. Communication Research, 38(4), 451-470.

Beldad, A. D. (2015). Sharing to be sociable, posting to be popular: Factors influencing non-static personal information disclosure on Facebook among young Dutch users. International Journal of Web Based Communities, 11(3-4), 357-374.

Bentler, P. M., \& Chou, C. (1987). Practical Issues in Structural Modeling. Sociological Methods \& Research, 16(1), 78-117.

Berger, J., \& Milkman, K. L. (2012). What makes online content viral? Journal of Marketing Research, 49(2), 192-205.

Burroughs, S., Brocato, K., Hopper, P. F., \& Sanders, A. (2009). Media literacy: A central component of democratic citizenship. Educational Forum, 73(2), 154-167.

Byrne, B. (2016). Structural equation modeling with AMOS: Basic concepts, applications, and programming. Routledge.

Carey, M. C., \& Meyer, H. K. (2016). The influences of participation and moderation on the development of a sense of virtual community. International Journal of Web Based Communities, 
INTERNATIONAL JOURNAL OF ACADEMIC RESEARCH IN BUSINESS AND SOCIAL SCIENCES

Vol. 10, No. 11, 2020, E-ISSN: 2222-6990 @ 2020 HRMARS

12(4), 326-341.

Carlin, R. E. (2014). What's not to trust? Rubrics of political party trustworthiness in Chile and Argentina. Party Politics, 20(1), 63-77.

Chan, M., \& Guo, J. (2013). The Role of Political Efficacy on the Relationship Between Facebook Use and Participatory Behaviors: A Comparative Study of Young American and Chinese Adults. Cyberpsychology, Behavior and Social Networking, 16(6), 460-463.

Chang, W.-C. (2017). Media use, democratic values, and political participation: empirical evidence from Taiwan. Japanese Journal of Political Science, 18(03), 385-406.

Chetty, N., \& Alathur, S. (2019). Racism and social media: A study in Indian context. International Journal of Web Based Communities, 15(1), 44-61.

Cheung, C. K., \& Xu, W. (2016). Promoting media literacy education in China: a case study of a primary school. International Journal of Adolescence and Youth, 21(2), 215-217.

Coleman, S., Morrison, D. E., \& Svennevig, M. (2008). New media and political efficacy. International Journal of Communication, 2(1), 771-791.

Conroy, M., Feezell, J. T., \& Guerrero, M. (2012). Facebook and political engagement: A study of online political group membership and offline political engagement. Computers in Human Behavior, 28(5), 1535-1546.

Correa, T., Hinsley, A. W., \& de Zúñiga, H. G. (2010). Who interacts on the Web?: The intersection of users' personality and social media use. Computers in Human Behavior, 26(2), 247-253.

Dauda, S., Mohamad, B., \& Muda, S. (2016). New Perspectives to Political Participation among Youth : The Impact of Facebook Usage. International Soft Science Conference, 127-134.

Demetriou, K. N. (2013). Democracy in transition: Political participation in the european union. In Democracy in Transition: Political Participation in the European Union. Springer-Verlag Berlin Heidelberg.

Dimitrova, D. V., Shehata, A., Stromback, J., Nord, L. W., Strömbäck, J., \& Nord, L. W. (2014). The Effects of Digital Media on Political Knowledge and Participation in Election Campaigns: Evidence From Panel Data. Communication Research, 41(1), 95-118.

Edgerly, S., Thorson, K., Bighash, L., \& Hannah, M. (2016). Posting about politics: Media as resources for political expression on Facebook. Journal of Information Technology and Politics, 13(2), 108125.

Effing, R., Hillegersberg, J. Van, \& Huibers, T. (2011). Social Media and Political Participation: Are Facebook, Twitter and YouTube Democratizing Our Political Systems? Electronic Participation, 6847(April 2011), 25-35.

Eristi, B., \& Erdem, C. (2017). Development of a Media Literacy Skills Scale. Contemporary Educational Technology, 8(3), 249-267.

Fenton, N. (2011). Alternative Media and Social Networking Sites: The Politics of Individuation and Political Participation. The Communication Review, 14(3), 179-196.

Hafez, M. H. M. (2016). "Facebook" usage during election campaigns and its impact on voters" attitudes and decisions towards political candidates. Cairo University.

Hair, J. F., Black, W. C., Babin, B. J., \& Anderson, R. E. (2010). Multivariate data analysis: A global perspective. Pearson: Upper Saddle River, NJ.

Hair, J. F., Black, W. C., Babin, B. J., \& Anderson, R. E. (2014). Multivariate Data Analysis. Pearson Education Limited.

Harper, C. (2017). Being more media savvy won't stop the spread of "fake news"-here's why. The 
INTERNATIONAL JOURNAL OF ACADEMIC RESEARCH IN BUSINESS AND SOCIAL SCIENCES Vol. 10, No. 11, 2020, E-ISSN: 2222-6990 @ 2020 HRMARS

Conversation. https://phys.org/news/2017-05-media-savvy-wont-fake-newshere.html

Hassan, M. S., Sah Allam, S. N., Mohamed Azim, A. M., Mahbob, M. H., \& Daud, M. A. (2020). Measuring the Integrity of Young People Political Participation: Psychometric Analysis of Media Literacy. International Journal of Academic Research in Business and Social Sciences, 10(2), 122. https://doi.org/10.6007/IJARBSS/v10-i2/6857

Hassan, M. S., Sah Allam, S. N., Mohd Azni, Z., \& Khamis, M. H. (2013). Social media and political participation among young people. Jurnal Sains Sosial, 1(1), 95-114.

Hj Mak Din, H. A., \& Stapa, Z. (2016). Penekanan Nilai Dalam Konteks Pemilihan Kepimpinan. Tinta Artikulasi Membina Ummah 2(1), 2(1), 51-58.

Hobbs, R. (2003). Measuring The Acquisition of Media-Literacy Skills. Reading Research Quarterly, 38(3), 330-355.

Hobbs, R. (2010). Digital and Media Literacy: A Plan of Action. http://www.knightcomm.org/wpcontent/uploads/2010/12/Digital_and_Media_Literacy_A_Plan_of_Action.pdf

Holt, K., Shehata, A., Strömbäck, J., \& Ljungberg, E. (2013). Age and the effects of news media attention and social media use on political interest and participation: Do social media function as leveller? European Journal of Communication, 28(1), 19-34.

Husnu, A. H., \& Mamat, S. A. (2016). The role of cyber trooper in malaysian politics 2008-2014 (Vol. 2016, Issue November).

Iskander, E. (2011). The Arab Spring | Connecting the National and the Virtual: Can Social Media Have a Role in Institution-building After Egypt's January 25 Uprising? International Journal of Communication, 5(1), 1225-1237.

Joko, E. P., Othman, Z., \& Damit, S. A. (2016). Belia dan Kelangsungan Hegemoni Barisan Nasional: Kajian Kes Pilihan Raya Umum 13 di Sabah. Jurnal Komunikasi Borneo Edisi Khas, 1-18.

Kaid, L. L., McKinney, M. S., \& Tedesco, J. C. (2007). Introduction: Political Information Efficacy and Young Voters. American Behavioral Scientist, 50(9), 1093-1111.

Kalogeropoulos, A., Negredo, S., Picone, I., \& Nielsen, R. K. (2017). Who Shares and Comments on News?: A Cross-National Comparative Analysis of Online and Social Media Participation. Social Media and Society, 3(4).

Kasmani, M. F., Sabran, R., \& Ramle, N. A. (2014). Who is tweeting on \#PRU13? Asian Social Science, 10(18), 144-157.

Koc, M., \& Barut, E. (2016). Development and validation of New Media Literacy Scale (NMLS) for university students. Computers in Human Behavior, 63(October 2016), 834-843.

Kumar, P. (2016). Young adults and aggression: A comparative study of gender differences. The International Journal of Indian Psychology, 3(4), 57.

Kumar, R., \& Thapa, D. (2014). Social media as a catalyst for civil society movements in India: A study in Dehradun city. New Media \& Society, 1(1), 1-18.

Kümpel, A. S., Karnowski, V., \& Keyling, T. (2015). News Sharing in Social Media: A Review of Current Research on News Sharing Users, Content, and Networks. Social Media + Society, 1(2), 1-14.

Lee, L. (2005). Young people and the Internet. Young, 13(4), 315-326.

Lewis, J., \& Jhally, S. (1998). The struggle over media literacy. Journal of Communication, 48(1), 109120.

Literat, I. (2014). Measuring new media literacies: Towards the development of a comprehensive assessment tool. Journal of Media Literacy Education, 6(1), 15-27.

Maamari, B. E., \& Zein, H. E. (2013). The Impact of Social Media on the Political Interests of the Youth 
INTERNATIONAL JOURNAL OF ACADEMIC RESEARCH IN BUSINESS AND SOCIAL SCIENCES

Vol. 10, No. 11, 2020, E-ISSN: 2222-6990 @ 2020 HRMARS

in Lebanon at the Wake of the Arab Spring. Social Science Computer Review, 32(4), 496-505.

Marsh, H. W., \& Hau, K.-T. (1996). Assessing Goodness of Fit : Is Parsimony Always Desirable ? The Journal of Experimental Education, 64(4), 364-390.

Martin, P. S. (2008). The mass media as sentinel: Why bad news about issues is good news for participation. Political Communication, 25(2), 180-193.

Marwick, A. E., \& Boyd, D. (2011). I tweet honestly, I tweet passionately: Twitter users, context collapse, and the imagined audience. New Media and Society, 13(1), 114-133.

Marwick, A. E., \& Boyd, D. (2014). Networked privacy: How teenagers negotiate context in social media. New Media \& Society, 16(7), 1051-1067.

Milner, H. (2007). The Political Knowledge and Political Participation of Young Canadians and Americans Americans. In The American University of Paris (Issue 56).

Min, Y. (2004). News Coverage of Negative Political Campaigns : An Experiment of Negative Campaign Effects on Turnout and Candidate Preference. Harvard International Journal of Press/Politics, 95-111.

Mohamed, A. S. P., Sulaiman, S. H., Othman, M. F., Che Jumaat Yang, M. A., \& Haron, H. (2011). Patriotism Dilemma Among Malaysian Youth: Between Strategy And Reality. International Journal of Business and Social Science, 2(16), 219-227.

Mohd Sani, M. A. (2014). The social media election in Malaysia: The 13th general election in 2013. Kajian Malaysia, 32(March 2008), 123-147.

Möller, J., De Vreese, C. H., Esser, F., \& Kunz, R. (2014). Pathway to Political Participation: The Influence of Online and Offline News Media on Internal Efficacy and Turnout of First-Time Voters. American Behavioral Scientist, 58(5).

Nisbet, E. C., \& Myers, T. a. (2011). Anti-American Sentiment as a Media Effect? Arab Media, Political Identity, and Public Opinion in the Middle East. Communication Research, 38(5), 684-709.

Norhayati, M. S. (2008). Pilihan Raya Umum Ke-12 (Pru-12 ): “ Tsunami " Politik Melayu ? Jebat: Malaysian Journal of History, Politics \& Strategic Studies, 35(April), 49-64.

Ojebuyi, B. R., \& Salawu, A. (2015). Media Literacy, Access and Political Participation among South African Black Youth: A Study of North-West University, Mafikeng Campus. Journal of Communication, 6(1), 207-218.

Oliveira, C., \& Garcia, A. C. B. (2019). Citizens' electronic participation: A systematic review of their challenges and how to overcome them. International Journal of Web Based Communities, 15(2), 123-150.

Omelicheva, M. Y., \& Ahmed, R. (2017). Religion and politics: examining the impact of faith on political participation. Religion, State and Society, 00(00), 1-22.

Pandian, S. (2014). University students and voting behavior in General Elections: Perceptions on Malaysian political parties leadership. Asian Social Science, 10(18), 225-231.

Pathak-shelat, M. (2014). Media Literacy and Well-Being of Young People. In Handbook of Child WellBeing (pp. 2057-2092.). Springer Netherlands.

Persson, M. J. (2013). Does education cause participation in politics? University of Gothenburg.

Picone, I., De Wolf, R., \& Robijt, S. (2016). Who Shares What with Whom and Why?: News sharing profiles amongst Flemish news users. Digital Journalism, 4(7), 921-932.

Pinkleton, B. E., \& Austin, E. W. (2002). Exploring Relationships Among Media Use Frequency, Perceived Media Importance, and Media Satisfaction in Political Disaffection and Efficac. Mass Communication and Society, 5(2), 207-228. 
INTERNATIONAL JOURNAL OF ACADEMIC RESEARCH IN BUSINESS AND SOCIAL SCIENCES

Vol. 10, No. 11, 2020, E-ISSN: 2222-6990 @ 2020 HRMARS

Pinkleton, B. E., Austin, E. W., Zhou, Y., Willoughby, J. F., \& Reiser, M. (2012). Perceptions of News Media, External Efficacy, and Public Affairs Apathy in Political Decision Making and Disaffection. Journalism \& Mass Communication Quarterly, 89(1), 23-39.

Plotkowiak, T. (2014). The Influence of Social Capital on Information Diffusion in Twitter's InterestBased Social Networks (Issue 4231). The University of St. Gallen.

Roy, S. (2016). Significance of Media Education in India. International Journal of E-Gõvernment \& EBusiness Research, 2(1), 58-71.

Sah Allam, S. N., Hassan, M. S., Mohamed Azim, A. M., Maidin, A., \& Sakrani, S. N. R. (2020). Media Literacy Dimension in Reinforcing Political Participation Integrity Among Young People in Social Media. International Journal of Academic Research in Business and Social Sciences, 10(March), 309-329. https://doi.org/10.6007/IJARBSS/v10-i3/7053

Salman, A., \& Hasim, M. S. (2011). New Media and Democracy : The Changing Political Landscape in Malaysia. Akademika, 81(1), 15-21.

Salman, A., \& Saad, S. (2015). Online Political Participation: A Study of Youth Usage of New Media. Mediterranean Journal of Social Sciences, 6(4). https://doi.org/10.5901/mjss.2015.v6n4s3p88

Sheedy, C. S. (2011). Social media for social change: a case study of social media use in the 2011 Egyptian revolution. Capstone Project, 28(4), 1-58.

Stockemer, D. (2012). Students' political engagement: A comprehensive study of University of Ottawa undergraduate students. Journal of Youth Studies, 15(8), 1028-1047.

Sudin, M. N. (2017). Berulangkah "tsunami" politik bandar? Utusan Online. http://www.utusan.com.my/rencana/utama/berulangkah-8216-tsunami-8217-politik-bandar1.459718

Taneja, H., Webster, J. G., Malthouse, E. C., \& Ksiazek, T. B. (2012). Media consumption across platforms: Identifying user-defined repertoires. New Media and Society, 14(6), 951-968.

Tang, G., \& Lee, F. L. F. F. (2013). Facebook Use and Political Participation: The Impact of Exposure to Shared Political Information, Connections With Public Political Actors, and Network Structural Heterogeneity. Social Science Computer Review, 31(6), 763-773.

Tedesco, J. C. (2011). Political Information Efficacy and Internet Effects in the 2008 U.S. Presidential Election. American Behavioral Scientist, 55(6), 696-713.

Toepfl, F. (2014). Four facets of critical news literacy in a non-democratic regime: How young Russians navigate their news. European Journal of Communication, 29(1), 68-82.

Trenz, H.-J. \& C. G. (2015). Civic engagement through mainstream online newspapers : potential and shortcomings Civic engagement through mainstream online newspapers: Possibilities and shortcomings Cecilie Givskov and Hans-Jörg Trenz. Journal of Media and Communication Research, 56(JANUARY 2014), 44-60.

Valenzuela, S. (2012). Protesting in the age of social media: Information, opinion expression and activism in online networks. Latin American Public Opinion Congress, World Association for Public Opinion Research (WAPOR), July, 1-38.

Valenzuela, S. (2013). Unpacking the Use of Social Media for Protest Behavior: The Roles of Information, Opinion Expression, and Activism. American Behavioral Scientist, 57(7), 920-942.

Valenzuela, S., Park, N., Kee, K. F., Valenzuela, S., Park, N., \& Kee, K. F. (2009). Is there social capital in a social network site?: Facebook use and college students' life satisfaction, trust, and participation. Journal of Computer-Mediated Communication, 14(4), 875-901.

Wolfsfeld, G., Yarchi, M., \& Samuel-Azran, T. (2015). Political information repertoires and political 
INTERNATIONAL JOURNAL OF ACADEMIC RESEARCH IN BUSINESS AND SOCIAL SCIENCES

Vol. 10, No. 11, 2020, E-ISSN: 2222-6990 @ 2020 HRMARS

participation. New Media \& Society, 1(1), 1-20.

Yamamoto, M., \& Kushin, M. J. (2014). More harm than good? Online media use and political disaffection among college students in the 2008 election. Journal of Computer-Mediated Communication, 19(3), 430-445.

Yamamoto, M., Kushin, M. J., \& Dalisay, F. (2013). Social media and mobiles as political mobilization forces for young adults: Examining the moderating role of online political expression in political participation. New Media \& Society, 0(0), 1-19.

Yang, H. C. "Chris," \& DeHart, J. L. (2016). Social Media Use and Online Political Participation Among College Students During the US Election 2012. Social Media + Society, 1(1), 1-18.

Yoo, S. W., \& Gil de Zuniga, H. (2014). Connecting blog, Twitter and Facebook use with gaps in knowledge and participation. Communication and Society, 27(4), 33-48.

Young, J. A., \& Marcos, S. (2016). Assessing New Media Literacies in Social Work Education: The Development and Validation of a Comprehensive Assessment Instrument. The Journal of Technology in Human Services, 33(1), 72-86.

Zhang, X., \& Lin, W.-Y. (2014). Political participation in an unlikely place: how individuals engage in politics through social networking sites in China. International Journal of Communication, 8(1), 22. 